\title{
The Combination of DGT Technique and Traditional Chemical Methods for Evaluation of Cadmium Bioavailability in Contaminated Soils with Organic Amendment
}

\author{
Yu Yao ${ }^{1}$, Qin Sun ${ }^{1, *}$, Chao Wang ${ }^{1}$, Pei-Fang Wang ${ }^{1, *}$, Ling-Zhan Miao ${ }^{1}$ and Shi-Ming Ding ${ }^{2}$ \\ 1 Key Laboratory of Integrated Regulation and Resource Development on Shallow Lakes, Ministry of \\ Education, College of Environment, Hohai University, Nanjing 210098, China; yu2011358@163.com (Y.Y.); \\ cwang@hhu.edu.cn (C.W.); mlz1988@126.com (L.-Z.M.) \\ 2 State Key Laboratory of Lake Science and Environment, Nanjing Institute of Geography and Limnology, \\ Chinese Academy of Sciences, Nanjing 210008, China; smding@niglas.ac.cn \\ * Correspondence: sunqinnj@hhu.edu.cn (Q.S.); pfwang2005@hhu.edu.cn (P.-F.W.); \\ Tel./Fax: +86-25-8378-6971 (Q.S.); +86-25-8378-7332 (P.-F.W.)
}

Academic Editor: Yu-Pin Lin

Received: 21 March 2016; Accepted: 9 June 2016; Published: 15 June 2016

\begin{abstract}
Organic amendments have been proposed as a means of remediation for Cd-contaminated soils. However, understanding the inhibitory effects of organic materials on metal immobilization requires further research. In this study colza cake, a typical organic amendment material, was investigated in order to elucidate the ability of this material to reduce toxicity of Cd-contaminated soil. Available concentrations of $\mathrm{Cd}$ in soils were measured using an in situ diffusive gradients in thin films (DGT) technique in combination with traditional chemical methods, such as HOAc (aqua regia), EDTA (ethylene diamine tetraacetic acid), $\mathrm{NaOAc}$ (sodium acetate), $\mathrm{CaCl}_{2}$, and labile $\mathrm{Cd}$ in pore water. These results were applied to predict the $\mathrm{Cd}$ bioavailability after the addition of colza cake to Cd-contaminated soil. Two commonly grown cash crops, wheat and maize, were selected for $\mathrm{Cd}$ accumulation studies, and were found to be sensitive to $\mathrm{Cd}$ bioavailability. Results showed that the addition of colza cake may inhibit the growth of wheat and maize. Furthermore, the addition of increasing colza cake doses led to decreasing shoot and root biomass accumulation. However, increasing colza cake doses did lead to the reduction of $\mathrm{Cd}$ accumulation in plant tissues, as indicated by the decreasing $\mathrm{Cd}$ concentrations in shoots and roots. The labile concentration of $\mathrm{Cd}$ obtained by DGT measurements and the traditional chemical extraction methods, showed the clear decrease of $\mathrm{Cd}$ with the addition of increasing colza cake doses. All indicators showed significant positive correlations $(p<0.01)$ with the accumulation of $\mathrm{Cd}$ in plant tissues, however, all of the methods could not reflect plant growth status. Additionally, the capability of $\mathrm{Cd}$ to change from solid phase to become available in a soil solution decreased with increasing colza cake doses. This was reflected by the decreases in the ratio $(R)$ value of $C_{\mathrm{DGT}}$ to $C_{\mathrm{sol}}$. Our study suggests that the sharp decrease in $R$ values could not only reflect the extremely low capability of labile $\mathrm{Cd}$ to be released from its solid phase, but may also be applied to evaluate the abnormal growth of the plants.
\end{abstract}

Keywords: organic amendment; colza cake; cadmium bioavailability; DGT extraction; extraction method; plant

\section{Introduction}

Cadmium $(\mathrm{Cd})$ is a non-essential element that is ubiquitously found in soil, water, and the atmosphere. Due to its high bioavailability and carcinogenic properties in humans, $\mathrm{Cd}$ has been 
blacklisted by the World Health Organization [1]. Cd is widely applied in industry for purposes such as electroplating, mining, and smelting, because of its metallic properties. This leads to the release of large amounts of $\mathrm{Cd}$ into soil through wastewater, irrigation, and sewage disposal [2]. The overuse of $\mathrm{Cd}$-containing pesticides and fertilizers may also increase the concentration of $\mathrm{Cd}$ in the soil [3]. Due to its widespread occurrence, and its bioaccumulating and biomagnifying effect throughout tropic chains, $\mathrm{Cd}$ monitoring has become an area of increased research focus [4,5]. Excavation, phytoremediation, leaching, electro remediation, solidification, and stabilization are some of the many engineering and chemical techniques that have been proposed to reduce $\mathrm{Cd}$ bioavailability in contaminated soils [6]. However, all of these methods have apparent disadvantages. Due to its comparatively high destruction of native organisms in the soil environment, the excavation approach can easily disrupt ecosystem stability and therefore, is not an eco-friendly method [7]. Phytoremediation and phytoextraction are more eco-friendly-based approaches that may also be long-lasting and cost-effective. Using these approaches, $\mathrm{Cd}$ is accumulated in plant tissues and removed from the soil through the harvest of these plants $[8,9]$. However, due to the high selectivity of the biotic for the target elements, the capacity of plants to contain $\mathrm{Cd}$, and the mobility of the element in soil, phytoremediation also does not supply an adequate solution to the reduction of $\mathrm{Cd}$ bioavailability in the soil [5]. Consequently, due to the severe implications of $\mathrm{Cd}$ contamination in the soil, the availability of a robust tool for the immobilization of Cd labile fractions is critical.

Previous investigations have shown performance inconsistencies of organic amendments in Cd contaminated soil. Some studies have revealed that the addition of organic materials might increase the ability of soil to bind the target element, making these contaminants available for removal through the remediation processes of sorption, precipitation, or complexation [9-12]. Yao et al. [5] have also indicated that typical organic pig manure could significantly reduce $\mathrm{Cd}$ toxicity interrestrial plants, such as wheat and maize. Additionally, the addition of organic materials could supply sufficient nutrients to plants and improve water retention in soil. Moreover, it was also reported that organic material can be beneficial by reducing phototoxicity and improving growth and survival of the biota $[6,13]$. Related studies have indicated that biochar, which may be the reactive group in the organic material, contains essential nutrients for plant germination and growth and, furthermore, could cover large areas to increase soil porosity and immobilize Cd fractions [14-17]. However, many investigations have also shown the increasing addition of the organic materials may enhance fraction mobility in soils and restrain biota growth $[6,9,10]$. Consequently, there are two prerequisites for organic materials that determine its applicability for soil amendment. One is that the organic amendment must be capable of reducing accumulated $\mathrm{Cd}$ in plant tissues during the plant's lifetime. The other prerequisite is that the addition of the organic material must benefit the plant biomass. Accordingly, further investigations on the effectiveness of organic amendments for the remediation of $\mathrm{Cd}$ contaminated soil are necessary to give the overall understanding of organic amendment application. Colza cake is the collected residue of rapeseed after the refining process and is a common fertilizer for cultivation. However, there are no systematic investigations explaining its effect on metal mobility and bioavailability in Cd contaminated soils. Accordingly, colza cake was applied as the amendment material in this study.

Diffusive gradients in thin films (DGT), as an in situ measurement, has become an increasingly popular method for constructing eco-security and early-warning systems $[18,19]$. This technique, based on Fick's first law, passively collects a target element while avoiding the influences of the base solution concentration and the surrounding environment [18]. The DGT device locally collects target element particles, while responding to fractions of resupplied labile species in a solution and the labile pools in the solid phase [19]. Consequently, the element concentration measured by the device is the mean concentration of the target element during deployment time. Due to the dynamic nature of the measurements, the DGT-measured concentration could effectively mimic the biota uptake process of metals such as $\mathrm{Cu}$ [20,21], Zn [20,22], $\mathrm{Cd}$ [21], and $\mathrm{Hg}$ [23,24]. Tian et al. [25] also demonstrated that the DGT obtained a concentration of a target element that was not influenced 
by the physiochemical properties of various metals and metalloids in soil, sediment, and water in the environment. Consequently, the use of DGT, as an in situ method, could dynamically reflect the bioavailability of $\mathrm{Cd}$ in soil. The traditional methods such as soil solution concentration [7], the free ion activity model, single or sequential extraction methods [26,27], and the isotope dilution exchange method are widely applied in the related investigations. These approaches have a lower time-cost ratio and simple operation procedures. These $e x$ situ methods are of great significance when evaluating $\mathrm{Cd}$ bioavailability in a static manner [28,29]. Due to the different advantages of the in situ and ex situ methods, both the DGT technique and traditional chemical methods were applied in this study to reflect the immobilization of labile $\mathrm{Cd}$ fractions after the addition of organic material.

Typical cash crops, wheat and maize, were used to accumulate Cd. The DGT technique and five traditional static testing methods, including soil solution concentration and four commonly used chemical extraction methods (chelating extractant EDTA (ethylene diamine tetraacetic acid), acid extractant $\mathrm{HOAc}$ (aqua regia), and salt solutions $\mathrm{CaCl}_{2}$ and $\mathrm{NaOAc}$ (sodium acetate)), were selected to evaluate how these approaches reflect $\mathrm{Cd}$ bioavailability. The aim of this study was to systematically investigate $\mathrm{Cd}$ bioavailability in $\mathrm{Cd}$-contaminated soil after the addition colza cake at varying concentrations. Pearson correlation coefficients, which determine differences between the bioavailable concentrations of $\mathrm{Cd}$ obtained by different indicators and the concentration of $\mathrm{Cd}$ accumulated in plant tissues, were used to compare bioaccumulation. The ratio of the DGT-measured concentration and the labile fractions in the soil solution under different addition concentrations of colza cake were also shown to reflect the resupply of labile $\mathrm{Cd}$ fractions. This further demonstrated the interaction between colza cake and labile Cd.

\section{Experimental}

\subsection{Soil Samples and Incubation}

Soil used in this study was collected from a suburb of Nanjing city in Jiangsu Province, China, which has adopted the "inter-planting mode" with paddy rice and wheat. Basic properties of this soil have been previously described [5]. Collected soil was typically yellow-brown in color, which is observed to be widespread in China. To ensure there was no point source of pollution, the collected soil samples were collected at a depth which was deeper than $20 \mathrm{~cm}$. The soil samples were then sieved with a $2 \mathrm{~mm}$ stainless steel mesh after being air-dried at room temperature.

Soil subsamples were mixed with $\mathrm{CdCl}_{2}$ to achieve a $4.0 \mathrm{mg} \cdot \mathrm{kg}^{-1} \mathrm{Cd}$ concentration to create $\mathrm{Cd}$-contaminated soil. Colza cake was then added as an organic amendment at eight different concentrations $\left(\mathrm{g} \cdot \mathrm{kg}^{-1}\right)$ in the soil. The treatments were CK (control treatment without addition of $\mathrm{Cd}$ and colza cake), $0,5.0,10.0,20.0,40.0,60.0,80.0$, and $100 \mathrm{~g} \cdot \mathrm{kg}^{-1}$. The $\mathrm{CaCl}_{2}$ solution and colza cake were thoroughly mixed with the sieved soil samples. To ensure the full aging of the experimental soil, all of the soils were incubated at room temperature for 36 months prior to the pot experiment. The soils were moistened with deionized water during the aging period, and were mixed once a week in order to ensure the full equilibration between naturally-occurring soil components and the amendment fractions.

\subsection{Greenhouse Pot Experiment}

Wheat and maize were grown in pots containing $750 \mathrm{~g}$ of the Cd-contaminated soils with different doses of colza cake. The soil moisture was maintained at $70 \%$ to $80 \%$ field water capacity with addition of deionized water. Fifteen wheat seeds and seven maize seed were sown in every experimental soil type with three replicates for every concentration. After germination, plant numbers were reduced to 10 wheat seedlings and five maize seedlings in every pot. All plants were grown under the natural day-night cycle in a greenhouse with no additional nutrients. After six weeks, all plants were harvested and separated into shoots and roots. Plant shoots were cut with scissors, cleaned with tap water, and further rinsed with deionized water to remove soil. Harvested plant roots were placed in a 
$20 \mathrm{mmol} \cdot \mathrm{L}^{-1}$ EDTA solution for $15 \mathrm{~min}$ and then washed with deionized water in order to remove fine particles adsorbed into the root surface. Shoots and roots were dried in an oven at $70{ }^{\circ} \mathrm{C}$ for $4 \mathrm{~h}$ to destroy chlorophyll and then the temperature was reduced to $50{ }^{\circ} \mathrm{C}$ until the tissue weight was constant. Cadmium concentrations in the plant tissues were determined by atomic absorption spectrophotometry (Z-81001, Hitachi Ltd., Hitachi, Japan) following digestion with $\mathrm{HNO}_{3} / \mathrm{HClO}_{4}$. To ensure accuracy, increase precision, and reduce experimental error $(<5 \%)$, quality control (GBW(E) 081581, Bureau of Standard Measurement, Beijing , China) of the analytical method was conducted every ten samples using a certified standard solution [5]. After harvest, the remaining soil samples were air-dried at room temperature and then sieved with a $2 \mathrm{~mm}$ stainless steel mesh for analysis of various parameters (described below).

\subsection{Analytical Methods of the Bioavailable Cd in Soils}

\subsubsection{In Situ DGT Measurement}

The principle of DGT is defined by the diffusion of dissolved species through a well-defined gel and subsequent accumulation on an ion-exchange resin. To control and astrict the accumulation concentration of the target element, a diffusion gel and a filter membrane are commonly used as the diffusive layer. The resin gel, which serves as a binding agent, is incorporated into a second polyacrylamide gel. The concentrations of the target elements are measured, including the fractions in pore water near the device surface and the fractions resupplied from solution, as well as that continuously released from the sediments.

A standard piston-type DGT device purchased from DGT Research Limited Corporation [30] was composed of a plastic base, a resin gel, a diffusive gel, a protective membrane filter, and a plastic cap (Figure 1). The diffusive gel $(0.8 \mathrm{~mm}$ thick) was prepared with $15 \%$ acrylamide and $0.3 \%$ agarose-derived cross-linker following a published procedure [18]. The resin gel ( $0.4 \mathrm{~mm}$ thick) was synthesized by infusing Chelex-100 into the diffusive gel. In the DGT assembly, the resin gel was sequentially covered by a diffusion gel and a $0.13 \mathrm{~mm}$ cellulose nitrate filter membrane $(0.45 \mu \mathrm{m}$ pore size. Whatman, Maidstone, UK) [18].

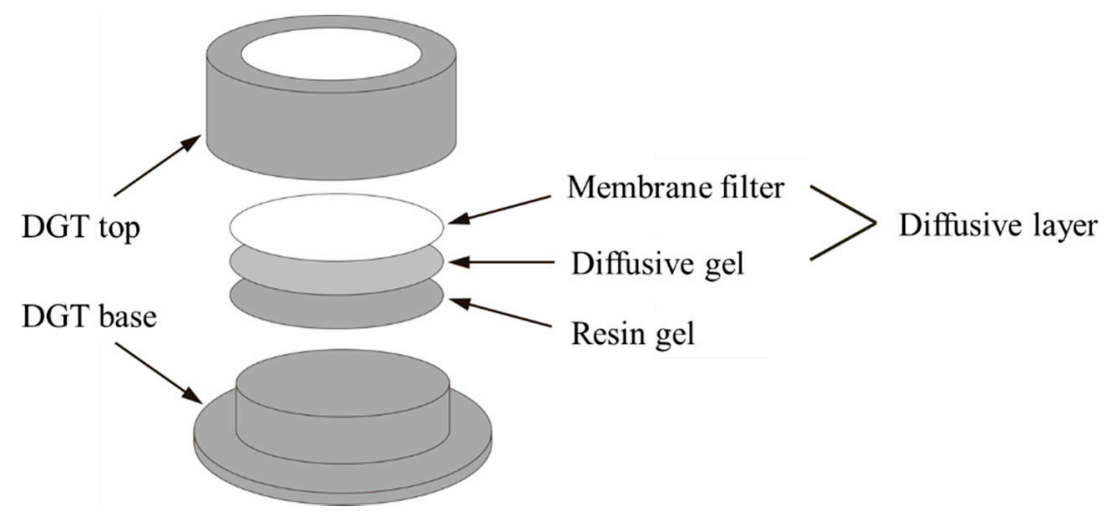

Figure 1. Component of a DGT device.

DGT device application in soil was based on a published procedure by Luo et al. [7]. The procedure was divided into the following five steps:

1. Subsample Moisture Adjustment

To ensure there was a complete equilibrium between fractions and soil, an $80 \mathrm{~g}$ subsample of each soil sample was placed in a plastic pot and maintained to $80 \%$ maximum water holding capacity (MWHC) with deionized water at $25^{\circ} \mathrm{C}$ for $48 \mathrm{~h}$. Water content was replenished to $80 \% \mathrm{MWHC}$ for $24 \mathrm{~h}$ before DGT deployment. 


\section{DGT Accumulation}

The DGT devices were gently pressed on to the surface of each subsample, in the plastic pot, and remained in position for $24 \mathrm{~h}$. To ensure that moisture was stable in the subsample, a cultivating dish was used to cover the DGT device (Figure 2). Temperature was controlled to be constant at $25 \pm 1{ }^{\circ} \mathrm{C}$ during DGT deployment.

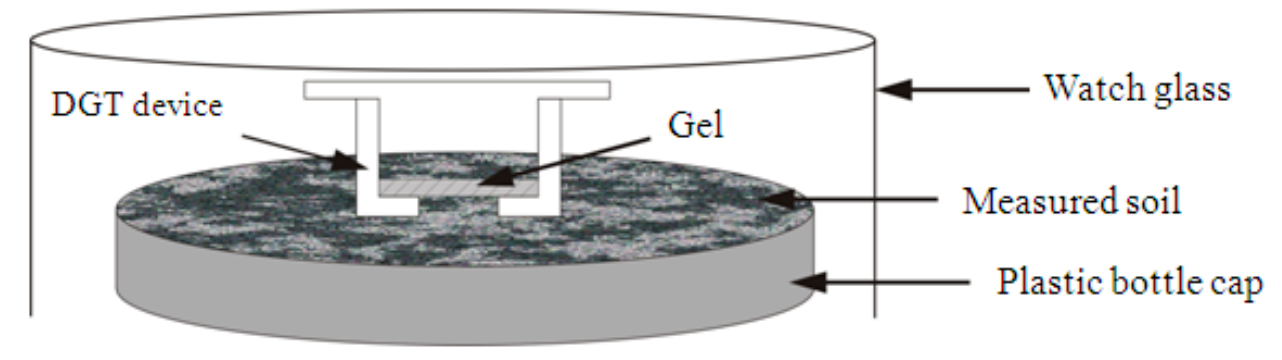

Figure 2. Schematic view of DGT deployment in soil.

3. Retrieval of the DGT Device

All DGT devices were retrieved after $24 \mathrm{~h}$. Deionized water was applied to wash the filter membrane in order to remove soil particles that had adhered to the DGT device surface. Rinsed DGT devices were sealed in a Ziploc bag in order to avoid drying of resin within the device.

\section{DGT Elution}

After the DGT device was disassembled, the resin gels were transferred into a centrifuge tube with $1 \mathrm{~mL}$ of $1 \mathrm{~mol} \cdot \mathrm{L}^{-1}$ nitric acid and then shaken for $24 \mathrm{~h}$. Cd concentrations eluted by nitric acid were measured using flame atomic absorption spectrophotometry (Hitachi Z-81001).

\section{Calculation of the DGT-Measured Concentrations}

The DGT-measured mass of Cd (M) in the resin gel was calculated according to the Equation (1) when a known volume of eluting solution was used for elution $\left(V_{s}\right)$ :

$$
\mathrm{M}=\frac{C_{e}\left(V_{g}+V_{S}\right)}{f_{e}}
$$

where $V_{g}$ is the volume of the resin gel, $0.2 \mathrm{~mL}$, and $f_{e}$ is the elution factor, 0.8 [18].

The concentrations of $C d$ measured by DGT $\left(C_{D G T}\right)$ were calculated using Equation (2):

$$
C_{D G T}=\frac{M \Delta g}{D A t}
$$

where $M$ is the accumulated mass of Cd over the deployment time (ng). $\Delta g$ is the thickness of the diffusive layer $(\mathrm{cm})$. D is the diffusion coefficient of $C d$ in the diffusive layer $\left(\mathrm{cm}^{2} \cdot \mathrm{s}^{-1}\right)$, which has been reported in a DGT website (www.dgtresearch.com). A is the area of DGT exposure window $\left(\mathrm{cm}^{2}\right)$ and $t$ is the time of DGT deployment (s) [18].

\subsubsection{Ex Situ Measurement}

Single Extraction Methods

Four widely-sed single extraction methods were selected to extract the labile Cd fractions in $\mathrm{Cd}$-contaminated soil after the addition of varying concentrations of colza cake. The chemical agents used during extractions were $0.05 \mathrm{~mol} \cdot \mathrm{L}^{-1} \mathrm{EDTA}, 0.11 \mathrm{~mol} \cdot \mathrm{L}^{-1} \mathrm{HOAc}, 1 \mathrm{~mol} \cdot \mathrm{L}^{-1} \mathrm{NaOAc}$, and 
$0.01 \mathrm{~mol} \cdot \mathrm{L}^{-1} \mathrm{CaCl}_{2}$. Among these four extraction agents, the common chelating agent EDTA had the strongest binding strength with complex ion fractions existing in the soil. The use of $0.11 \mathrm{~mol} \cdot \mathrm{L}^{-1}$ HOAc was reported to influence biota growth and it was the first step in a three-step extraction procedure recommended by the Standards, Measurements, and Testing Program (SM and T) of the European Commission [31]. $\mathrm{NaOAc}$ and $\mathrm{CaCl}_{2}$ are typically used in ion exchange-based methods because, as weak substitution agents, they could be used to evaluate labile fractions through the replacement of their cation.

To avoid extractant overheating, all solutions were centrifuged at $3000 \mathrm{~g}$ for $20 \mathrm{~min}$ at $25^{\circ} \mathrm{C}$. The supernatants were then filtered with plastic strainers, transferred to $10 \mathrm{~mL}$ centrifuge tubes with $\mathrm{HNO}_{3}$, and subsequently stored at $4{ }^{\circ} \mathrm{C}$ prior to analysis. All extraction procedures were conducted in triplicate. Details of these operations are listed in Table 1.

Table 1. The procedures of four extraction methods adopted in this study.

\begin{tabular}{lll}
\hline Extractants & Procedure & References \\
\hline \multirow{2}{*}{ EDTA } & $\begin{array}{l}2.0 \mathrm{~g} \text { of soil was extracted with } 20 \mathrm{~mL} \text { of } \\
0.05 \mathrm{~mol} \cdot \mathrm{L}^{-1} \mathrm{EDT} \text { Aadjusted using an ammonia } \\
\text { solution to } \mathrm{pH}=7.0 \text { and shaken for } 2 \mathrm{~h}\end{array}$ & Wear and Evans (1968) [32] \\
\hline HOAc & $\begin{array}{l}0.5 \mathrm{~g} \text { of soil was extracted with } 20 \mathrm{~mL} \text { of } \\
0.11 \mathrm{~mol} \cdot \mathrm{L}^{-1} \mathrm{HOAc} \text { and shaken for } 16 \mathrm{~h} \text { (overnight) }\end{array}$ & Houba et al. (1996) [29] \\
\hline \multirow{2}{*}{$\mathrm{NaOAc}$} & $\begin{array}{l}4.0 \mathrm{~g} \text { of soil was extracted with } 20 \mathrm{~mL} \text { of } 1 \mathrm{~mol} \cdot \mathrm{L}^{-1} \\
\text { NaOAc and shaken for } 2 \mathrm{~h}\end{array}$ & Kaplan et al. (2009) [33] \\
\hline $\mathrm{CaCl}_{2}$ & $\begin{array}{l}2.0 \mathrm{~g} \text { of soil was extracted with } 20 \mathrm{~mL} \mathrm{of} \\
0.01 \mathrm{~mol} \cdot \mathrm{L}^{-1} \mathrm{CaCl}_{2} \text { and shaken for } 3 \mathrm{~h}\end{array}$ & Novozamsky et al. (1993) [34] \\
\hline
\end{tabular}

Soil Solution Concentration

Soil subsamples from which the deployed DGT were collected were centrifuged at 10,000 $\mathrm{g}$ for $20 \mathrm{~min}$ at $25^{\circ} \mathrm{C}$ to obtain a soil paste. A $0.45 \mu \mathrm{m}$ pore size cellulose nitrate filter membrane was used to filter the paste and ensure the purity of the samples. The solutions were acidified using $\mathrm{HNO}_{3}$.

The concentration of $\mathrm{Cd}$ in extracts and soil solutions was measured using atomic absorption spectrophotometry (Hitachi Z-81001). Certified standard solutions and duplicates of all samples were applied to ensure accuracy and precision. For each test of the standard solutions, all obtained metal concentrations agreed with the certified values within the expected range of experimental error $(<5 \%)$. Relative standard deviations based on the mean values obtained for each sample type were less than $5 \%$ [5].

\subsection{Data Analyses}

Statistical analyses were performed using the SPSS statistical package (version 10.0 for Windows, IBM, New York, NY, USA). The data for shoot and root dry weights were tested at a significance level of $p<0.05$ by one-way ANOVA analysis of variance. The relationship between various bioavailable indicators of $\mathrm{Cd}$, measured by six methods in soils, and plant $\mathrm{Cd}$ uptake were investigated using the Pearson correlation coefficient.

\section{Results and Discussion}

\subsection{Plant Growth and Accumulation in Response to Colza Cake Exposure}

Colza cake is a commonly applied organic material for fertilization in China. It is rich in N and $\mathrm{P}$, and has sufficient protein content, which is comprised of approximately $30 \%$ crude protein and $25 \%$ easy to decompose protein [35,36]. As shown in Figure 3, the growth of wheat was not affected by single $\mathrm{Cd}$ treatment $\left(4.0 \mathrm{mg} \cdot \mathrm{kg}^{-1}\right)$, however, the growth of maize was clearly inhibited by single $\mathrm{Cd}$ addition, 
its biomass of shoot and root were significantly $(p<0.05)$ decreased by $21 \%$ and $19 \%$, respectively, compared with the control plant tissues (CK). Moreover, colza cake addition in Cd-contaminated soils may inhibit the biota growth to a large extent, which was indicated by the decreased biomass of wheat and maize. Similar investigations have indicated contradictory conclusions, where the addition of organic materials, such as straw manure, which could significantly promote the growth of radish in $\mathrm{Cd}$ and $\mathrm{Cu}$ contaminated soil, and such as chicken manure amendments, which could increase $\mathrm{Pb} / \mathrm{Cu}$ accumulation in Brassica chinensis and sunflower [37]. In addition, these results provide contrary evidence to the varying trend of $\mathrm{Cd}$ accumulation in plant tissues. The concentration of $\mathrm{Cd}$ in the tissues of wheat and maize are displayed in Figure 4. Colza cake, as an additive, clearly restricted $\mathrm{Cd}$ accumulation in the shoots and roots of both plants and its inhibitory effects increased with increasing doses. Cd concentrations in shoots and roots were decreased by $71 \%$ and $83 \%$ for wheat, and by $61 \%$ and $77 \%$ for maize, respectively, when the added amount of colza cake was at least $100 \mathrm{~g} \cdot \mathrm{kg}^{-1}$. Previous investigations have indicated the addition of organic materials to soil may theoretically increase plant biomass, could optimize physicochemical properties, such as the nutrient concentrations of $\mathrm{Fe}, \mathrm{Mn}, \mathrm{Cu}$, and $\mathrm{Zn}$, as well as soil acidity and alkalinity, which benefit biota growth [11,38]. However, due to the characteristics of heat production, the application of colza cake could easily cause the loss of elements, such as N, P, and K. In addition, the extremely high concentration of colza cake could also lead to withering and death of roots. As a result, the biomass of wheat and maize plants were sharply decreased after the addition of high concentrations of colza cake $\left(60-100 \mathrm{~g} \cdot \mathrm{kg}^{-1}\right)$ [11]. In view of this phenomenon, we thought that the effects of organic amendments to the Cd contaminated soil could be dependent upon the release mechanism of the fertilizer. Similar studies have shown that colza cake may release superabundant nutrients to become dissolved into the soil solution, which led to changes in the concentration gradients between the water and cells. This causes extreme water loss within cells and results in plasmolysis [13,14].
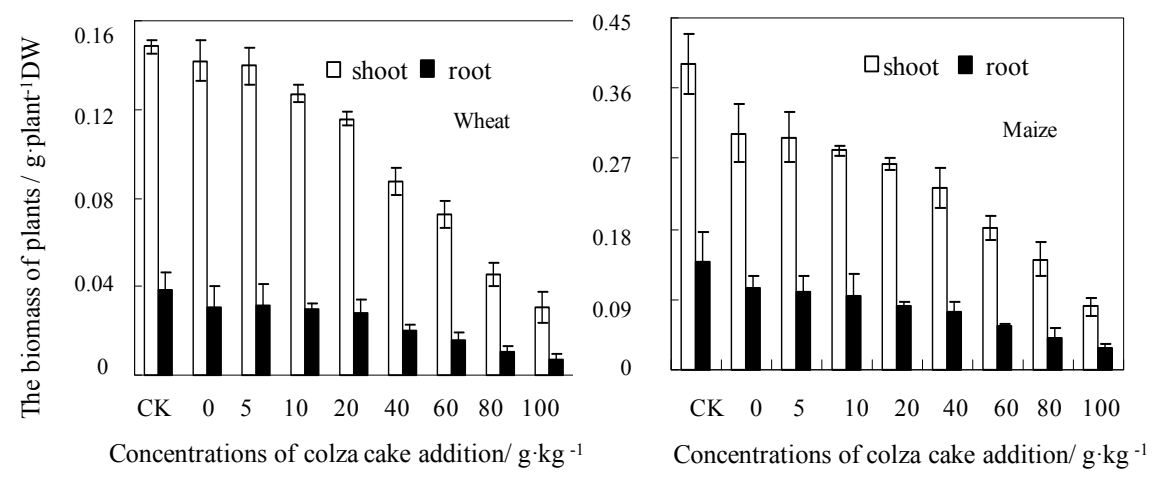

Figure 3. Effects of colza cake addition on the biomass (expressed as dry weight) of wheat and maize in Cd-contaminated soils.
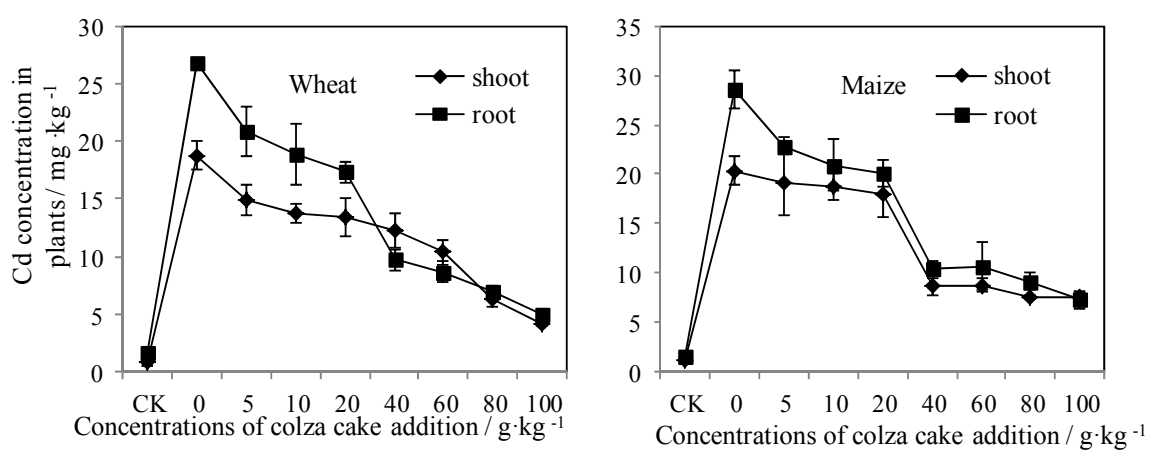

Figure 4. Cadmium concentrations in plant tissues of wheat and maize after the addition of colza cake in Cd-contaminated soils. 


\subsection{Bioavailable Cd Reflected by a Dynamic Measurement}

In order to provide a robust tool to evaluate the effects of organic amendments on $\mathrm{Cd}$ concentrations in contaminated soil, a novel in situ technique using DGT was applied to mimic the accumulation of $\mathrm{Cd}$ in plant tissues. DGT is a rapid and dynamic technique based on the Fick's first law, which is used to measure concentration of a target element. This depends upon diffusion-controlled fluxes of a solute from the surface of the DGT device to the resin gel (binding phase). The DGT technique measures labile species, with the exclusion of kinetically-inert organic species, large colloids, and strong organic-metal complexes. The dynamic nature of its measurements ensures that information obtained from contaminated soils is a result of the average concentration during the DGT device deployment $[18,39]$. These characteristics also aid in the avoidance of analytical errors, which can arise due to the uneven distribution of labile fractions [7]. Therefore, the labile concentration measured by DGT could serve as a model for the ability of organisms to uptake the target element from the extract solution supplied by the solid state of the element in soil, although DGT obtained concentration information was limited and controlled by the diffusion quantification in the diffusion layer [40]. Several studies have indicated that the DGT method has great advantages in predicting the bioavailability of metals, such as $\mathrm{Zn}, \mathrm{Pb}, \mathrm{Cu}$, and $\mathrm{As}$, after the addition of organic materials, and was sensitive to changes in bioavailable fractions without the influence of the complex physic-chemical properties $[20,24,41]$. Consequently, DGT can be used as a robust tool to evaluate metal bioavailability in soils and evaluate metal accumulation by plants after the addition of colza cake.

As presented in Figure 5, the DGT-labile concentrations of $C d\left(C_{\text {DGT }}\right)$ in soils, in which wheat and maize were grown, significantly decreased with the addition of increasing doses of colza cake. This trend positively correlated with lower $\mathrm{Cd}$ accumulation in shoots and roots of biota after addition of colza cake. Results of DGT indicated that the addition of colza cake can be effective in reducing the concentration of bioavailable $\mathrm{Cd}$ in $\mathrm{Cd}$-contaminated soils. The increased proportion of organic-bound $\mathrm{Cd}$ in soil resulted in a significant decrease in Cd mobility. Consequently, it was concluded that the application of the DGT method could reflect the bioavailability of $\mathrm{Cd}$ in a soil solution after the addition of colza cake, and/or the decrease in the rate of resupply of $\mathrm{Cd}$ to solution from the solid phase. However, the excessive addition of colza cake could lead to growth retardation in wheat and maize and, as a result, the DGT method could not predict plant growth status. Many investigations have indicated that the simulation of DGT has neglected the microenvironment in the vicinity of the rhizosphere, and the effects of naturally-occurring microorganisms on roots [40].
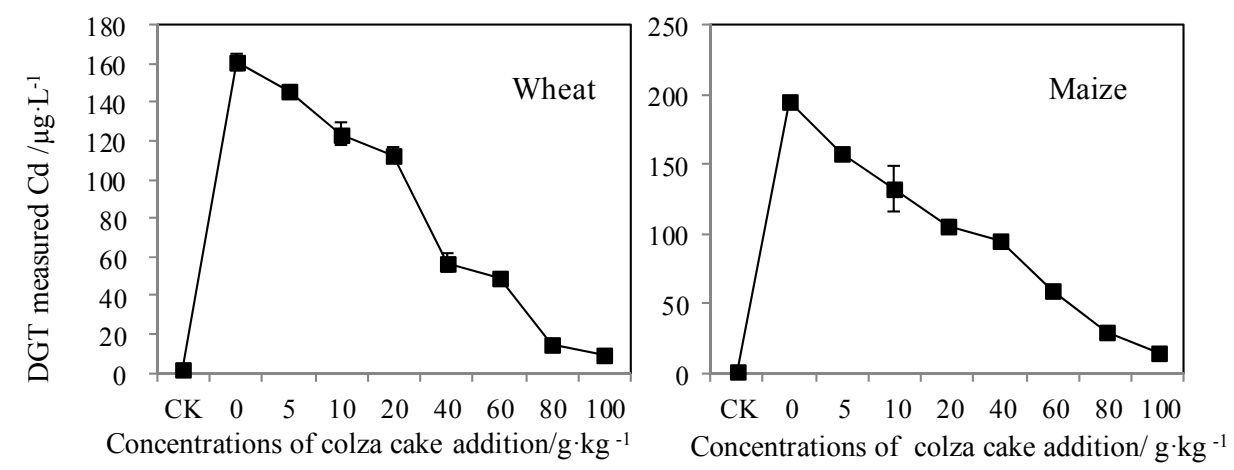

Figure 5. DGT-measured concentrations $\left(C_{\mathrm{DGT}}\right)$ of $\mathrm{Cd}$ after the addition of colza cake in Cd-contaminated soils grown by wheat and maize, respectively.

\subsection{Bioavailable Cd Reflected by Static Measurements}

\subsubsection{Soil Solution Concentration of $\mathrm{Cd}$}

Due to the direct uptake of mineral elements by the roots of biota from the soil solution, several researchers have indicated that measuring total dissolved $\mathrm{Cd}$ in soil solutions is a more direct method to 
evaluate the potential for $\mathrm{Cd}$ accumulation in biota [42-44]. Until now, heavy metals that accumulate in biota were divided into two categories; heavy metal fractions that are metabolically-available, and heavy metal fractions that are no longer bioavailable [45]. Accordingly, dissolved Cd may be represented by the accumulated $\mathrm{Cd}$ concentration in biota, but it could not represent the relative toxicity to the biota. Moreover, there were few reports on the effect of soil solution which was applied to evaluate the $\mathrm{Cd}$ bioavailability after the addition of organic materials. Further investigation was necessary to establish a comprehensive understanding of soil solution evaluation. As shown in Figure 6, the $\mathrm{Cd}$ concentration in a soil solution $\left(C_{\text {sol }}\right)$ after planting two plants considerably decreased with the addition of increasing doses of colza cake. This trend was similar to the trend seen using DGT. The addition of colza cake could significantly decrease the dissolved concentration of $\mathrm{Cd}$ when compared to $\mathrm{Cd}$-contaminated soils with no colza cake addition. The concentration of $\mathrm{Cd}$ was reduced by $11 \%$ to $87 \%$ for wheat, and by $8 \%$ to $91 \%$ for maize, when the added amounts varied from 5.0 to $100 \mathrm{~g} \cdot \mathrm{kg}^{-1}$. Beesley et al. [11] produced similar results when they reported a significant decrease in Cd and $\mathrm{Zn}$ concentrations in pore water with the addition of biochar and green waste compost. As indicated in this study, the $\mathrm{Cd}$ concentration in soil solutions could not reflect the growth status of wheat and maize after the addition of colza cake. Colza cake, without composting, was difficult to dissolve in a soil solution. As a result, excess colza cake may inhibit the clearing of the soil particles, which may lead to the build-up of an anaerobic environment near roots, the lack of nutrient availability, and overall biota growth retardation.
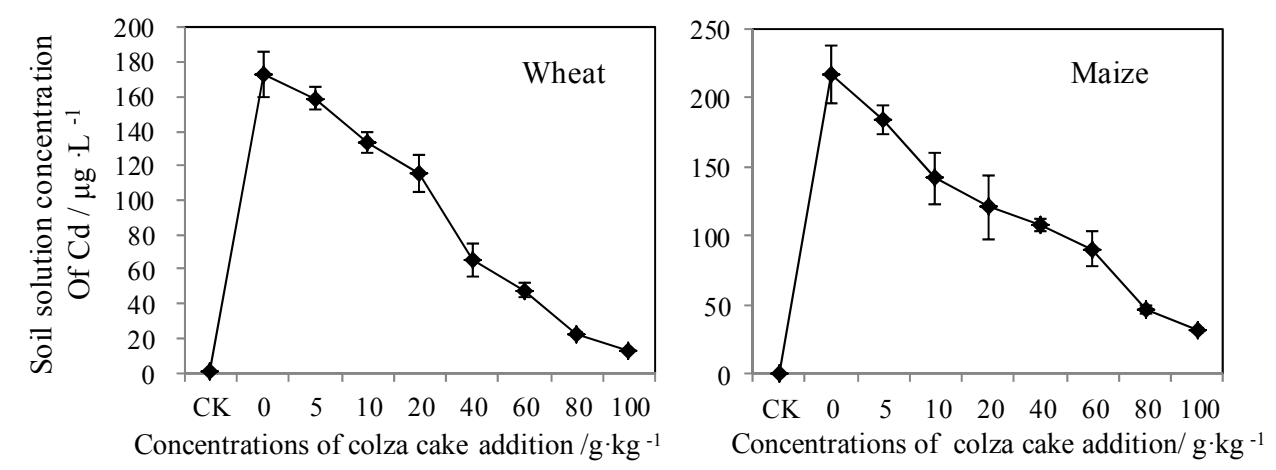

Figure 6. Soil solution concentrations $\left(C_{\text {sol }}\right)$ of $C d$ after the addition of colza cake in $C d$-contaminated soils grown by wheat and maize, respectively.

\subsubsection{Bioavailable Cd Reflected by Traditional Extraction Measurements}

The chemical agents used in traditional extraction methods could be used to evaluate the mobilization of different $\mathrm{Cd}$ fractions in Cd-contaminated soil after the addition of organic amendments $[8,9,46]$. However, many investigations have reported that measurements of heavy metal concentrations using these chemical agents were arbitrary and had no direct connection with fraction accumulation in biota [26,47]. To further verify the utilization of these extraction measurements, as well as to investigate the variations in $\mathrm{Cd}$ concentrations with the addition of colza cake, it was essential to evaluate the effects of chemical agents on $\mathrm{Cd}$ bioavailability. The concentrations of $\mathrm{Cd}$ measured by the four extraction chemicals (HOAc, EDTA, $\mathrm{NaOAc}$, and $\mathrm{CaCl}_{2}$ ) are shown in Figure 7 . The $\mathrm{Cd}$ concentration, as measured using the four extraction chemicals, decreased with the addition of increased doses of colza cake. Based on the varying intensity of the extractions, the four reagents were applied to selectively release fractions on exchange sites or carbonate phase, and release metals bound to soil organic matter [29,41,47-49]. For the soils in which wheat and maize were grown, variation in the extracted amounts of $\mathrm{Cd}$ with four extractants had similar trends as results for $\mathrm{Cd}$ concentrations in soils measured by DGT, as indicated by the gradual decreases in $\mathrm{Cd}$ concentration with increasing additions of colza cake. However, because of the higher percentage of fraction redistribution and 
readsorption, the decreases in $\mathrm{Cd}$ concentration after colza cake addition seen with the use of $\mathrm{NaOAc}$ and $\mathrm{CaCl}_{2}$ occurred at a slower pace in comparison to EDTA and HOAc.
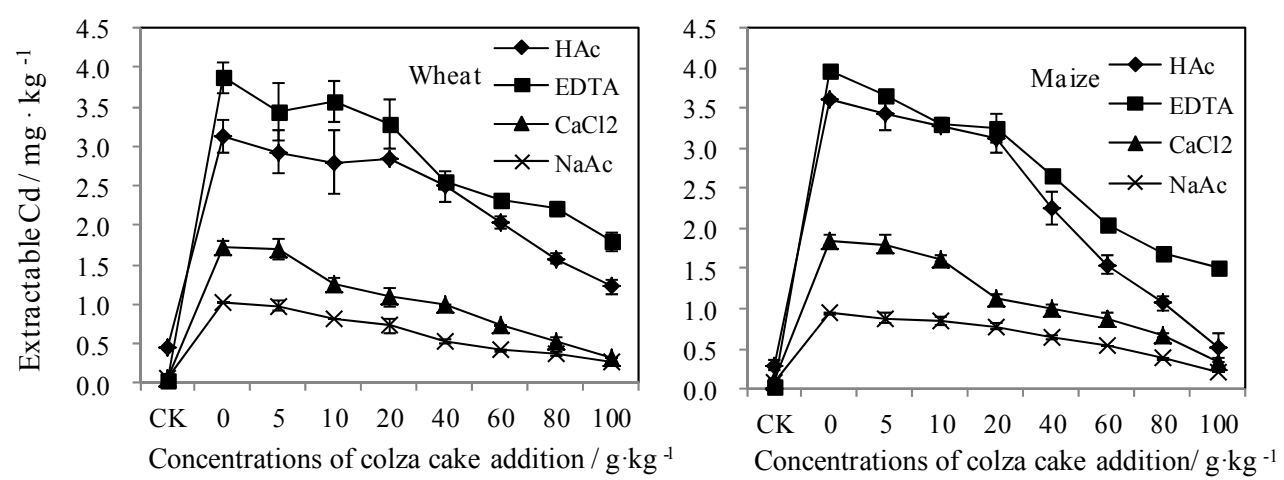

Figure 7. The bioavailable concentrations of $\mathrm{Cd}$ measured by different extraction methods after the addition of colza cake in Cd-contaminated soils grown by wheat and maize, respectively.

Among the four extractants, EDTA extracted the largest amount of $\mathrm{Cd}$ from soils in comparison to $\mathrm{HOAc}, \mathrm{NaOAc}$, and $\mathrm{CaCl}_{2}$. Since EDTA was a chelating agent, it was strong enough to extract $\mathrm{Cd}$, which is bound to organic materials in the oxidation state generated by secondary clay minerals [26]. Following EDTA, it was hypothesized that HAc would extract more $\mathrm{Cd}$ from soils than the remaining two agents. HOAc acts as an acid extractant that can partially extract organic matter bound metals and release most bioavailable fractions that are coupled with calcium carbonate and minerals [50,51]. $\mathrm{NaOAc}$ and $\mathrm{CaCl}_{2}$ are weak neutral salts that can extract metal components on mineral surfaces based on the cation exchange principle [26,27]. Due to the low impact on the plant growing environment, the bioavailable fractions extracted by these solutions have been suggested to represent active sources in soils for plant uptake [42].

In this study, the decreasing $\mathrm{Cd}$ concentrations in EDTA, $\mathrm{HOAc}, \mathrm{NaOAc}$, and $\mathrm{CaCl}_{2}$ extracted solutions, as well as in soil solutions, indicated that the bioavailable species of $\mathrm{Cd}$ may be easily translated to inert form after the addition of colza cake. This was in agreement with the decreases observed using the DGT method (Figure 5). Coupled with dynamic measurements made using DGT, these static data, including soil solution $\mathrm{Cd}$ concentration measurements determined using the four extraction agents, further implied that the bioavailable fractions in soils were reduced after mixing colza cake with soil [52].

\subsection{The Inhibition to Cd Bioavailability Caused by Colza Cake}

As shown in Table 2, the linear relationships between $\mathrm{Cd}$ concentrations in plants and bioavailable concentrations of $\mathrm{Cd}$ were analyzed using the Pearson Correlation Coefficient (two-tailed). All these methods used to measure $\mathrm{Cd}$ concentrations in soil showed significantly positive relationships $(p<0.01)$ with accumulated $\mathrm{Cd}$ in plant tissues. Comparing the correlation coefficients obtained by the DGT technique with those obtained by traditional approaches revealed no substantial differences. Several investigations have revealed the discernible advantages of using the DGT device for evaluating heavy metal bioavailability in soil compared to the traditional extraction methods $[18,20,49]$. The indiscrimination between the results of DGT-measured Cd concentrations and Cd concentrations obtained from the traditional methods were due to the influence of colza cake. 
Table 2. The Pearson correlation coefficients $(r)$ of the 24 samplers between Cd concentrations in the plant tissues and bioavailable concentrations of $\mathrm{Cd}$ measured by six methods.

\begin{tabular}{cccccccc}
\hline $\begin{array}{c}\text { Plant } \\
\text { Species }\end{array}$ & $\begin{array}{c}\text { Plant } \\
\text { Tissues }\end{array}$ & DGT & $\begin{array}{c}\text { Soil } \\
\text { Solution }\end{array}$ & HAc & EDTA & NaAc & CaCl $_{2}$ \\
\hline \multirow{2}{*}{ wheat } & shoot & $0.971^{* *}$ & $0.967^{* *}$ & $0.883^{* *}$ & $0.966^{* *}$ & $0.956^{* *}$ & $0.890^{* *}$ \\
& root & $0.979^{* *}$ & $0.979^{* *}$ & $0.894^{* *}$ & $0.974^{* *}$ & $0.975^{* *}$ & $0.934^{* *}$ \\
\hline \multirow{2}{*}{ maize } & shoot & $0.974^{* *}$ & $0.972^{* *}$ & $0.954^{* *}$ & $0.961^{* *}$ & $0.971^{* *}$ & $0.933^{* *}$ \\
& root & $0.970^{* *}$ & $0.962^{* *}$ & $0.944^{* *}$ & $0.969^{* *}$ & $0.936^{* *}$ & $0.949^{* *}$ \\
\hline \multicolumn{7}{c}{ Correlation is significant at the level of $p<0.01}$. &
\end{tabular}

The mobilization of target elements in the soil dramatically impacted their bioavailability, which was indicated by the diffusion intensity of the resupplied element from the solid phase to soil solution $[20,50,51]$. Accordingly, the ratio of $C_{\text {DGT }}$ to $C_{\text {sol }}(R)$ was used to reflect the extent to which metals were resupplied to the soil solution from solid phase [19]. The $R$ value varies from 0 to 1 , with a value close to 1 indicating a very rapid resupply of the element (i.e., the sustained case) and a value close to 0.1 indicating very slow resupply (the diffusive case). A medium $R$ value between 1 and 0.1 is referred to as the partial case [51]. As listed in Table 3, the $R$ values gradually decreased with increasing additions of colza cake. However, the obvious decreases in this trend were observed when the additions of colza cake were up to $60 \mathrm{~g} \cdot \mathrm{kg}^{-1}$. Yao et al. [5] used pig manure to mitigate the bioavailability of $\mathrm{Cd}$ in the same $\mathrm{Cd}$-contaminated soil. The $\mathrm{R}$ values in their study also showed a decreasing trend with the addition of pig manure, but the $R$ values decreased at a significantly slower pace than the $R$ values observed after the addition of colza cake. We speculated that the watertight nature of colza cake may be responsible for the extremely small $R$ values when the addition concentrations of colza cake were more than $60 \mathrm{~g} \cdot \mathrm{kg}^{-1}$.

Table 3. The calculated ratio $(R)$ values of the DGT-measured concentrations $\left(C_{\mathrm{DGT}}\right)$ of $\mathrm{Cd}$ to soil solution concentrations $\left(C_{\mathrm{sol}}\right)$ of $\mathrm{Cd}$ with increasing addition of colza cake in soils.

\begin{tabular}{ccc}
\hline Colza Cake Levels in Soil $\left(\mathbf{g} \cdot \mathbf{~ k g}^{-\mathbf{1}}\right)$ & Wheat & Maize \\
\hline CK & 0.83 & 0.85 \\
0 & 0.73 & 0.74 \\
5.0 & 0.71 & 0.69 \\
10.0 & 0.67 & 0.68 \\
20.0 & 0.63 & 0.65 \\
40.0 & 0.51 & 0.52 \\
60.0 & 0.37 & 0.29 \\
80.0 & 0.31 & 0.21 \\
100.0 & 0.27 & 0.16 \\
\hline
\end{tabular}

CK represents the control group, $R=C_{\mathrm{DGT}} / C_{\mathrm{sol}}$.

\section{Conclusions}

Although the addition of colza cake could clearly reduce Cd bioavailability, the biomass of wheat and maize were significantly decreased with the addition of colza cake at increasing doses. Consequently, colza cake amendments may not be an effective method for the remediation of Cd-contaminated soil. The bioavailable Cd obtained by DGT and traditional chemical methods both showed similar variations with the accumulated $\mathrm{Cd}$ in plant tissues, as indicated by the positive significance analysis $(p<0.01)$. However, all of the selected indicators in this study could not reflect the growth status of the biota. These indicators gave a one-sided evaluation based on Cd bioavailability, while ignoring the negative effects of colza cake on the biota. Although that $R$ values (the ratio of $C_{\text {DGT }}$ to $C_{\text {sol }}$ ) could not only evaluate $C d$ bioavailability after the addition of colza cake but also reflect the growth condition of the wheat and maize in this study. However, due to the rate of the adsorption and 
desorption of the sorbed $\mathrm{Cd}$ fractions, future research will be necessary for the performance of the $R$ value.

Acknowledgments: This study was sponsored by the National Natural Scientific Foundation of China (No. 51479068, 41001334), State Key Laboratory of Lake Science and Environment (2014SKL011), and a project funded by the Priority Academic Program Development (PAPD) of Jiangsu Higher Education Institutions.

Author Contributions: Yu Yao, Qin Sun, Pei-Fang Wang, Ling-Zhan Miao, Chao Wang and Shi-Ming Ding conceived this study. Yu Yao and Qin Sun performed the experiments and analyzed the date. Yu Yao, Qin Sun, Pei-Fang Wang and Ling-Zhan Miao wrote the paper. All authors read and approved the final manuscript.

Conflicts of Interest: The authors declare no conflict of interest.

\section{References}

1. Järup, L.; Åkesson, A. Current status of cadmium as an environmental health problem. Toxicol. Appl. Pharmacol. 2009, 238, 201-208. [CrossRef] [PubMed]

2. Di Toppi, L.S.; Gabbrielli, R. Response to cadmium in higher plants. Environ. Exp. Bot. 1999, 41, 105-130. [CrossRef]

3. Das, P.; Samantaray, S.; Rout, G.R. Studies on Cadmium Toxicity in Plants: A Review. Environ. Pollut. 1997, 98, 29-36. [CrossRef]

4. Forsberg, L.S.; Kleja, D.B.; Greger, M. Effects of sewage sludge on solution chemistry and plant uptake of Cu in sulphide mine tailings at different weathering stages. Appl. Geochem. 2009, 24, 475-482. [CrossRef]

5. Yao, Y.; Sun, Q.; Wang, C.; Wang, P.F.; Ding, S.M. Evaluation of organic amendment on the effect of cadmium bioavailability in contaminated soils using the DGT technique and traditional methods. Environ. Sci. Pollut. Res. 2015, 8, 1-10. [CrossRef] [PubMed]

6. Lee, T.; Lai, H.; Chen, Z. Effect of chemical amendments on the concentration of cadmium and lead in long-term contaminated soil. Chemosphere 2004, 57, 1459-1471. [CrossRef] [PubMed]

7. Luo, J.; Zhang, H.; Zhao, F.J. Distinguishing diffusional and plant control of $\mathrm{Cd}$ and Ni uptake by hyper accumulator and nonhyper accumulator plants. Environ. Sci. Technol. 2010, 44, 6636-6641. [CrossRef] [PubMed]

8. Hartley, W.; Edwards, R.; Lepp, W.N. Arsenic and heavy metal mobility in iron oxide-amended contaminated soil evaluated by short and long-term leaching tests. Environ. Pollut. 2004, 131, 495-504. [CrossRef] [PubMed]

9. Antoniadis, V.; Alloway, B.J. The role of dissolved organic carbon in the mobility of $\mathrm{Cd}, \mathrm{Ni}$ and $\mathrm{Zn}$ in sewage sludge-amended soils. Environ. Pollut. 2002, 117, 515-521. [CrossRef]

10. Mohan, D.; Sarswat, A.; Sik, O.Y.; Charles, U.; Pittman, J. Organic and inorganic contaminants removal from water with biochar, a renewable, low cost and sustainable adsorbent-A critical review. Bioresour. Technol. 2014, 160, 191-202. [CrossRef] [PubMed]

11. Pietikainen, J.; Kiikkil, O.; Fritze, H. Charcoal as a habitat for microbes and its effect on the microbial community of the underlying humus. J. Hazard Mater. 2000, 89, 231-242. [CrossRef]

12. Venegas, A.; Rigol, A.; Vidal, M. Viability of organic wastes and biochars as amendments for the remediation of heavy metal-contaminated soils. Chemosphere 2015, 119, 190-198. [CrossRef] [PubMed]

13. Beesley, L.; Dickinson, N.M. Carbon and trace element mobility in an urban soil amended with green waste compost. J. Soils Sediment. 2010, 10, 215-222. [CrossRef]

14. Clemente, R.; Paredes, C.; Bernal, M.P. A field experiment investigating the effects of olive husk and cow manure on heavy metal availability in a contaminated calcareous soil from Murcia (Spain). Agric. Ecosyst. Environ. 2007, 118, 319-326. [CrossRef]

15. Khokhotva, O.; Waara, S. The influence of dissolved organic carbon on sorption of heavy metals on urea-treated pine bark. J. Hazard Mater. 2010, 173, 689-696. [CrossRef] [PubMed]

16. Carbonell, G.; De Imperial, R.M.; Torrijos, M. Effects of municipal solid waste compost and mineral fertilizer amendments on soil properties and heavy metals distribution in maize plants (Zea mays L.). Chemosphere 2011, 85, 1614-1623. [CrossRef] [PubMed]

17. Chaiyarat, R.; Suebsima, R.; Putwattana, N. Effects of soil amendments on growth and metal uptake by Ocimumgratissimum grown in Cd/Zn-contaminated soil. Water Air Soil Pollut. 2011, 214, 383-392. [CrossRef] 
18. Zhang, H.; Davison, W. Performance characteristics of diffusion gradients in thin films for the in situ measurement of trace metals in aqueous solution. Anal. Chem. 1995, 67, 3391-3400. [CrossRef]

19. Nowack, B.; Koehler, S.; Schulin, R. Use of diffusive gradients in thin films (DGT) in undisturbed Field Soils. Environ. Sci. Technol. 2004, 38, 1133-1138. [CrossRef] [PubMed]

20. Zhang, H.; Lombi, E.; Smolders, E. Kinetic of Zn release in soils and prediction of Zn concentration in plants using diffusive gradients in thin films. Environ. Sci. Technol. 2004, 38, 3608-3613. [CrossRef] [PubMed]

21. Teasdale, P.R.; Hayward, S.; Davison, W. In situ, high-resolution measurement of dissolved sulfide using diffusive gradients in thin films with computer imaging densitometry. Anal. Chem. 1999, 71, 2186-2191. [CrossRef] [PubMed]

22. Docekalova, H.; Divis, P. Application of diffusive gradient in thin films technique (DGT) to measurement of mercury in aquatic systems. Talanta 1999, 65, 1174-1178. [CrossRef] [PubMed]

23. Clarisse, O.; Hintelmann, H. Measurements of dissolved methylmercury in natural waters using diffusive gradients in thin film (DGT). Environ. Monit. 2006, 8, 1242-1247. [CrossRef] [PubMed]

24. Divis, P.; Szkandera, R.; Brulik, L. Application of New Resin Gels for Measuring Mercury by Diffusive Gradients ina Thin-films Technique. Anal. Sci. 2009, 25, 575-578. [CrossRef] [PubMed]

25. Tian, Y.; Wang, X.R.; Luo, J. Evaluation of holistic approaches to predicting the concentrations of metals in field-cultivated rice. Environ. Sci. Technol. 2008, 42, 7649-7654. [CrossRef] [PubMed]

26. Feng, M.H.; Shan, X.Q.; Zhang, S.Z. Comparison of a rhizosphere-based method with Other One-Step Extraction methods for assessing the bioavailability of soil metals to wheat. Chemosphere 2005, 59, 939-949. [CrossRef] [PubMed]

27. Menzies, N.W.; Donn, M.J.; Kopittke, P.M. Evaluation of extractants for estimation of the phytoavailable trace metals in soils. Environ. Pollut. 2007, 145, 121-130. [CrossRef] [PubMed]

28. Black, A.; McLaren, R.G.; Reichman, S.M. Evaluation of soil metal bioavailablity estimates using two plant species (L. perenne and T. aestivum) grown in a range of agricultural soils treated with biosolids and metal salts. Environ. Pollut. 2011, 159, 1523-1535. [CrossRef] [PubMed]

29. Houba, V.J.G.; Lexmond, T.M.; Novozamsky, I. State of the art and future developments in soil analysis for bioavailability assessment. Sci. Total Environ. 1996, 178, 21-28. [CrossRef]

30. DGT Research Limited Corporation. Available online: www.dgtresearch.com (accessed on 21 March 2016).

31. Ure, A.M.; Quevauviller, P.H.; Muntau, H. Speciation of heavy metals in soils and sediments. An account of the improvement and harmonization of extraction techniques undertaken under the auspices of the BCR of the commission of the European communities. Int. J. Environ. Anal. Chem. 1993, 51, 135-151. [CrossRef]

32. Wear, J.I.; Evans, C.E. Relationship of zinc uptake by corn and sorghum to soil zinc measured by three extractants. Soil Sci. Soc. Am. J. 1996, 32, 543-546. [CrossRef]

33. Kaplan, O.; Yaman, M.; Kaya, G. Distribution of nickel in different phases of soil samples and plant parts taken from serpentine and copper mining area. Asian J. Chem. 2009, 21, 5757-5767.

34. Novozamsky, I.; Lexmond, T.H.M.; Houba, V.J.G. A single extraction procedure of soil for evaluation of uptake of some heavy metals by plants. Int. J. Environ. Anal. Chem. 1993, 51, 47-58. [CrossRef]

35. Kos, B.; Leštan, D. Induced phytoextraction/soil washing of lead using biodegradable chelate and permeablebarriers. Environ. Sci. Technol. 2003, 37, 624-629. [CrossRef] [PubMed]

36. Amarowicz, R.; Fornal, J.; Karamac, M. Effect of seed moisture on phenolic acids in rapeseed oil cake. Grasas Aceites 1995, 46, 354-356. [CrossRef]

37. Tang, X.J.; Li, X.; Liu, X.M.; Muhammad, Z.H.; Xu, J.M.; Philip, C.B. Effects of inorganic and organic amendments on the uptake of lead and trace elements by Brassica Chinensis grown in an acidic red soil. Chemosphere 2015, 119, 177-183. [CrossRef] [PubMed]

38. Ahmad, M.; Rajapaksha, A.U.; Lim, J.E. Biochar as a sorbent for contaminant management in soil and water: A review. Chemosphere 2014, 99, 19-33. [CrossRef] [PubMed]

39. González-Núñez, R.; Alba, M.D.; Orta, M.M.; Rigol, A. Remediation of metal-contaminated soils with the addition of material-Part I: Characterization and viability studies for the selection of non-hazardous waste materials and silicates. Chemosphere 2011, 85, 1511-1517. [CrossRef] [PubMed]

40. Marijke, K.; Lucas, R.; Nathalie, R.; Willie, P. Comparison of the method of diffusive gels in thin films with conventional extraction techniques for evaluating zinc accumulation in plants and isopods. Environ. Pollut. 2005, 133, 103-116. 
41. Garmo, O.A.; Royset, O.; Steinnes, E. Performance study of diffusive gradients in thin films for 55 elements. Anal. Chem. 2003, 75, 3573-3580. [CrossRef] [PubMed]

42. McBride, M.B.; Nibarger, E.A.; Richards, B.K.; Steenhuis, T. Trace metal accumulation by red clover grown on sewage sludge-amended soils and correlation to Mehlich 3 and calcium chloride-extractable metals. Soil Sci. 2003, 168, 29-38. [CrossRef]

43. Kamewada, K.; Nakayama, M. Cadmium uptake by garland chrysanthemum can be predicted from the cadmium in the soil solution, independent of soil type. Soil Sci. Plant Nutr. 2009, 55, 441-451.

44. Paralelo, R.; Barral, M.T. Evaluation of the potential capacity as biosorbents of two MSW composts with different $\mathrm{Cu}, \mathrm{Pb}$ and $\mathrm{Zn}$ concentration. Bioresour. Technol. 2012, 104, 810-813.

45. Rainbow, P.S. Trace metal concentrations in aquatic invertebrates: Why and so what? Environ. Pollut. 2002, 120, 497-507. [CrossRef]

46. Sanka, M.; Dolezal, M. Prediction of Plant Contamination by Cadmium and Zinc Based on Soil Extraction Method and Contents in Seedlings. Int. J. Environ. Anal. Chem. 1992, 46, 87-96.

47. Tessier, A.; Campbell, P.G.C.; Bisson, M. Sequential extraction procedure for the speciation of particulate trace metals. Anal. Chem. 1979, 51, 844-851.

48. Payá-Pérez, A.; Sala, J.; Mousty, F. Comparison of ICP-AES and ICP-MS for the analysis of trace elements in soil extracts. Int. J. Environ. Anal. Chem. 1993, 51, 223-230.

49. Bade, R.; Oh, S.; Shin, W.S. Assessment of metal bioavailability in smelter-contaminated soil before and after lime amendment. Ecotox. Environ. Saf. 2012, 80, 299-307. [CrossRef] [PubMed]

50. Liu, L.; Chen, H.S.; Cai, P.; Wei, L.; Huang, Q.Y. Immobilization and phytotoxicity of Cd in contaminated soil amended with chicken manure compost. J. Hazard Mater. 2009, 163, 563-567. [PubMed]

51. Degryse, F.; Smolders, E.; Oliver, I. Relating soil solution Zn concentration to diffusive gradients in thin films measurements in contaminated soils. Environ. Sci. Technol. 2003, 37, 3958-3965. [CrossRef] [PubMed]

52. Harper, M.P.; Davison, W.; Tych, W. DIFS-a modelling and simulation tool for DGT induced trace metal remobilisation in sediments and soils. Environ. Modell. Softw. 2000, 15, 55-66. [CrossRef]

(C) 2016 by the authors; licensee MDPI, Basel, Switzerland. This article is an open access article distributed under the terms and conditions of the Creative Commons Attribution (CC-BY) license (http://creativecommons.org/licenses/by/4.0/). 